\title{
SEASONAL AND INTERANNUAL PATTERN OF METEOROLOGICAL VARIABLES IN CUIABÁ, MATO GROSSO STATE, BRAZIL
}

\author{
Nadja Gomes Machado 1,2, Marcelo Sacardi Biudes², Carlos Alexandre Santos Querino2,3, \\ Victor Hugo de Morais Danelichen ${ }^{4}$ and Maísa Caldas Souza Velasque ${ }^{2}$
}

\begin{abstract}
Cuiabá is located on the border of the Pantanal and Cerrado, in Mato Grosso State, which is recognized as one of the biggest agricultural producers of Brazil. The use of natural resources in a sustainable manner requires knowledge of the regional meteorological variables. Thus, the objective of this study was to characterize the seasonal and interannual pattern of meteorological variables in Cuiabá. The meteorological data from 1961 to 2011 were provided by the Instituto Nacional de Meteorologia (INMET - National Institute of Meteorology). The results have shown interannual and seasonal variations of precipitation, solar radiation, air temperature and relative humidity, and wind speed and direction, establishing two main distinct seasons (rainy and dry). On average, 89\% of the rainfall occurred in the wet season. The annual average values of daily global radiation, mean, minimum and maximum temperature and relative humidity were $15.6 \mathrm{MJ} \mathrm{m}^{-2} \mathrm{y}^{-1}, 27.9^{\circ} \mathrm{C}$, $23.0^{\circ} \mathrm{C}, 30.0^{\circ} \mathrm{C}$ and $71.6 \%$, respectively. The maximum temperature and the wind speed had no seasonal pattern. The wind speed average decreased in the NW direction and increased in the $\mathrm{S}$ direction.
\end{abstract}

Keywords: meteorological variables, climatology, ENSO.

RESUMO. Cuiabá está localizado na fronteira do Pantanal com o Cerrado, no Mato Grosso, que é reconhecido como um dos maiores produtores agrícolas do Brasil. A utilização dos recursos naturais de forma sustentável requer o conhecimento das variáveis meteorológicas em escala regional. Assim, 0 objetivo deste estudo foi caracterizar o padrão sazonal e interanual das variáveis meteorológicas em Cuiabá. Os dados meteorológicos de 1961 a 2011 foram fornecidos pelo Instituto Nacional de Meteorologia (INMET). Os resultados mostraram variações interanuais e sazonais de precipitação, radiação solar, temperatura e umidade relativa do ar e velocidade e direção do vento, estabelecendo duas principais estações distintas (chuvosa e seca). Em média, 89\% da precipitação ocorreu na estação chuvosa. Os valores médios anuais de radiação diária global, temperatura do ar média, mínima e máxima e umidade relativa do ar foram $15,6 \mathrm{MJ} \mathrm{m}^{-2} \mathrm{y}^{-1}, 27,9^{\circ} \mathrm{C}, 23,0^{\circ} \mathrm{C}, 30,0^{\circ} \mathrm{C}$ e $71,6 \%$, respectivamente. A temperatura máxima e a velocidade do vento não tiveram padrão sazonal. A velocidade média do vento diminuiu na direção NW e aumentou na direção S.

Palavras-chave: variáveis meteorológicas, climatologia, ENOS.

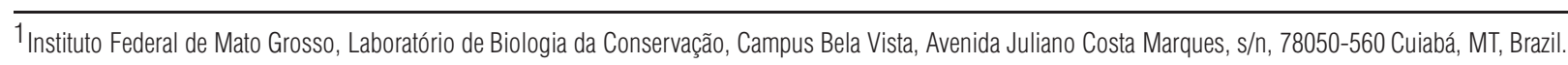
Phone: +55(65) 3318-5100 - E-mail: nadja.machado@blv.ffmt.edu.br

2 Universidade Federal do Mato Grosso, Programa de Pós-Graduação em Física Ambiental, Instituto de Física, Av. Fernando Corrêa da Costa, 2367, Cidade Universitária, Bloco de Física Ambiental, 78060-900 Cuiabá, MT, Brazil. Phone: +55(65)3615-8738 - E-mails: marcelo@fisica.ufmt.br; maisacaldass@hotmail.com

${ }^{3}$ Sistema de Proteção de Amazônia, Divisão de Meteorologia, Centro Regional de Porto Velho, Avenida Lauro Sodré, 6500, Aeroporto Porto Velho, $76803-260$ Porto Velho, R0, Brazil. Phone: +55(69) 3217-6316-E-mail: carlos.querino@sipam.gov.br

${ }^{4}$ Universidade de Cuiabá, Programa de Pós-Graduação em Ciências Ambientais, Rua Manoel José de Arruda, 3100, Bairro Jardim Europa, 78065-900 Cuiabá, MT, Brazil. Phone +55(65) 3363-1000-E-mail: danelichen@fisica.ufmt.br
} 


\section{INTRODUCTION}

Many studies has been developed about local and regional climate around the world (Gash \& Nobre, 1997; Leung et al., 2003; Xie et al., 2003; Christensen et al., 2008; Biudes et al., 2015), allowing researchers and decision-makers assess possible future climates, explore societal impacts, and approach policy responses from a risk-based perspective (Maurer et al., 2007). In summary, the climate is a generalization of the different weather conditions prevailing in a particular place and considers the frequency of meteorological phenomena more common place and conditions mean time (Diniz et al., 2008). The weather varies in a short period in time (i.e. one day) while the climate varies from one location to another mainly due to variations in intensity, amount and distribution of climatic elements, such as solar radiation, temperature, relative humidity, wind and precipitation (Pereira et al., 2002).

The largest fluctuations in solar radiation, air temperature and atmospheric humidity is associated with rainfall patterns, verifying that, at the time of the rainy season, there is a reduction in air temperature and solar radiation and an increasing in air humidity, occurring the opposite in periods of low rainfall (Bastos et al., 1997). The hydrologic cycle is an integral part of the climate, which links directly to the latent heat flux and evapotranspiration and has been affected by a continuous deforestation and burning, rising greenhouse gases concentration in the atmosphere and changing the national and regional hydrographic feature (Diniz et al., 2008; Biudes et al., 2009, 2012).

In recent years, many studies are concerned with the interaction between climatic conditions and land surface changing (Delire et al., 2004; Snyder et al., 2004; Bonan, 2008; Biudes et al., 2012, 2014a). The physical and biological factors of the surface determine the interaction between the atmospheric humidity, precipitation, runoff and energy balance in the form of latent and sensible heat (Diniz et al., 2008; Biudes et al., 2009). The microclimate changes in a specific region occur both by anthropogenic influences such as urbanization and agriculture (Kalnay \& Cai, 2003), and by alterations on the concentration of greenhouse gases (Biudes et al., 2014b; Souza et al., 2014).

The climatology studies have advanced in Brazil, but regional and local studies are still concentrated in the Southeast of Brazil, with some advances in the Northeast and North (Amazon Forest) and a great lack of information for the Midwest, making it necessary new approaches aimed at filling the gaps as the diversity of the Brazilian climate (Alves et al., 2011). The Midwest Climate is Tropical with dry winter and lower temperature between May and September and wet summer and higher temperature between
October and March and is very dependent of the South Atlantic Convergence Zone (SACZ) (Alves, 2009). The SACZ is characterized by an oriented NW/SE cloudiness band semi-stationary associated with a zone of convergence of moisture, which extends to the middle troposphere, during several days (4 to 20 days) and extending from the Amazon to South Atlantic Ocean (Rao et al., 1996). The Midwest temperature is also highly controlled by the geographical position and the terrain (altitude). The lowest elevation areas (such as the Pantanal) have high temperatures, while the highest areas (such as the Plateau of Mato Grosso and Goiás) have low temperatures (Gomes et al., 2012).

Mato Grosso State is recognized as one of the largest agricultural producers of the world, which is strongly influenced by climate, especially the occurrence and distribution of precipitation (Fietz et al., 2008). Mato Grosso is one of the states from Midwest region of Brazil, whose dominant climate is the tropical with a dry period occurring in the winter season (Aw according to Köppen Classification). On the other hand, the Northern region of Mato Grosso is a small portion where the monsoon climate takes place (Am according to Köppen Classification) (Peel et al., 2007). Based on total annual precipitation and duration of the rainy season, Mato Grosso can be divided into five homogeneous rainfall regions in which the North region has the highest pluviometric indices followed by Central, East and South, respectively (Fietz et al., 2008). The major climatological studies in Mato Grosso State were conducted specially on its capital Cuiabá by looking at the relation between micrometeorological variables and land use (Xavier et al., 2009; Callejas et al., 2011; Santos, 2013).

The soil of the region is dominated by unconsolidated alluvial deposits of the formation of the Pantanal, Quaternary fluvial origin of age. The terrain is slightly hilly and the altitude varies between 146 and $266 \mathrm{~m}$ (Zeilhofer, 2001). The vegetation of Cuiabá consists of remnants of Cerrado, Cerradão, riparian forests and exotic vegetation, represented by fruit, ornamentals and grasses (Guarim Neto, 1991).

The high amount of rivers and streams in urban area of Cuiabá, the large volume of precipitation during the wet season, the impermeability of the urban soil (asphalt and concrete) and the presence of obstructions (as garbage) have caused historical disasters by flooding (Zamparoni, 2012). In addition, there is no detailed research about the meteorological patterns in Cuiabá, which highlight the importance to study its climate. Thus, the present study aimed to characterize the seasonal and interannual pattern of the meteorological variables in Cuiabá, Mato Grosso State, Brazil. 


\section{MATERIAL AND METHODS}

\section{Study Area}

Cuiabá is located in the central southern of Mato Grosso State, between Cerrado and Pantanal, with an area of 22,851.10 km² (Fig. 1), bordering the municipalities of Jangada, Acorizal, Chapada dos Guimarães, Cuiabá, Várzea Grande, Nossa Senhora do Livramento, Rosário Oeste, Nobres, Alto Paraguai, Diamantino, Planalto da Serra, Nova Brasilândia and Campo Verde (Chiaranda et al., 2012). The regional climate is Aw according to Köppen classification, which represents a Semi-humid Tropical Climate (Brasil, 1997), or Tropical Savanna Climate (Brasil, 1982). The average annual rainfall is $1335 \mathrm{~mm}$ and its regime presents two distinct periods: rainy (October to April) and dry (May to September) (Chiaranda et al., 2012). The average of annual temperature ranges from 22 to $25^{\circ} \mathrm{C}$ (Brasil, 1997) and relative humidity is 74.3\% (Chiaranda et al., 2012).

\section{Data Collection and Analysis}

The data were obtained from Instituto Nacional de Meteorologia (INMET) between 1961 to 2011. As the data had gaps, we used only years with daily data for all days of the year. Were analyzed 25 years of solar radiation, 28 years of precipitation, 31 years of maximum temperature, 27 years of mean temperature, 29 years of minimum temperature, 28 years of relative humidity, 34 years of wind speed, and 26 years of wind direction (Table 1).

To analyze the occurrence of dry and rainy days were considered dry days when no precipitation occurred. Wind directions were specified according to Dallacort et al. (2010). They used the wind rose, which specifies eight wind directions and their symbology and degrees (Table 2). The predominant winds directions were characterized by the frequency analysis of daily observations from each month of the year. The daily average air temperature was calculated based on the compensated temperature equation Eq. (1):

$$
T_{\text {avg }}=\frac{\left(T_{\max }+T_{\min }+T_{12}+2 T_{24}\right)}{5}
$$

where $T_{\max }$ and $T_{\min }$ are the daily maximum and minimum temperature registered, $T_{12}$ is the temperature at noon GMT and $T_{24}$ is the air temperature at midnight GMT.

The Mann Whitney test (Wilks, 2011) was used to verify if the

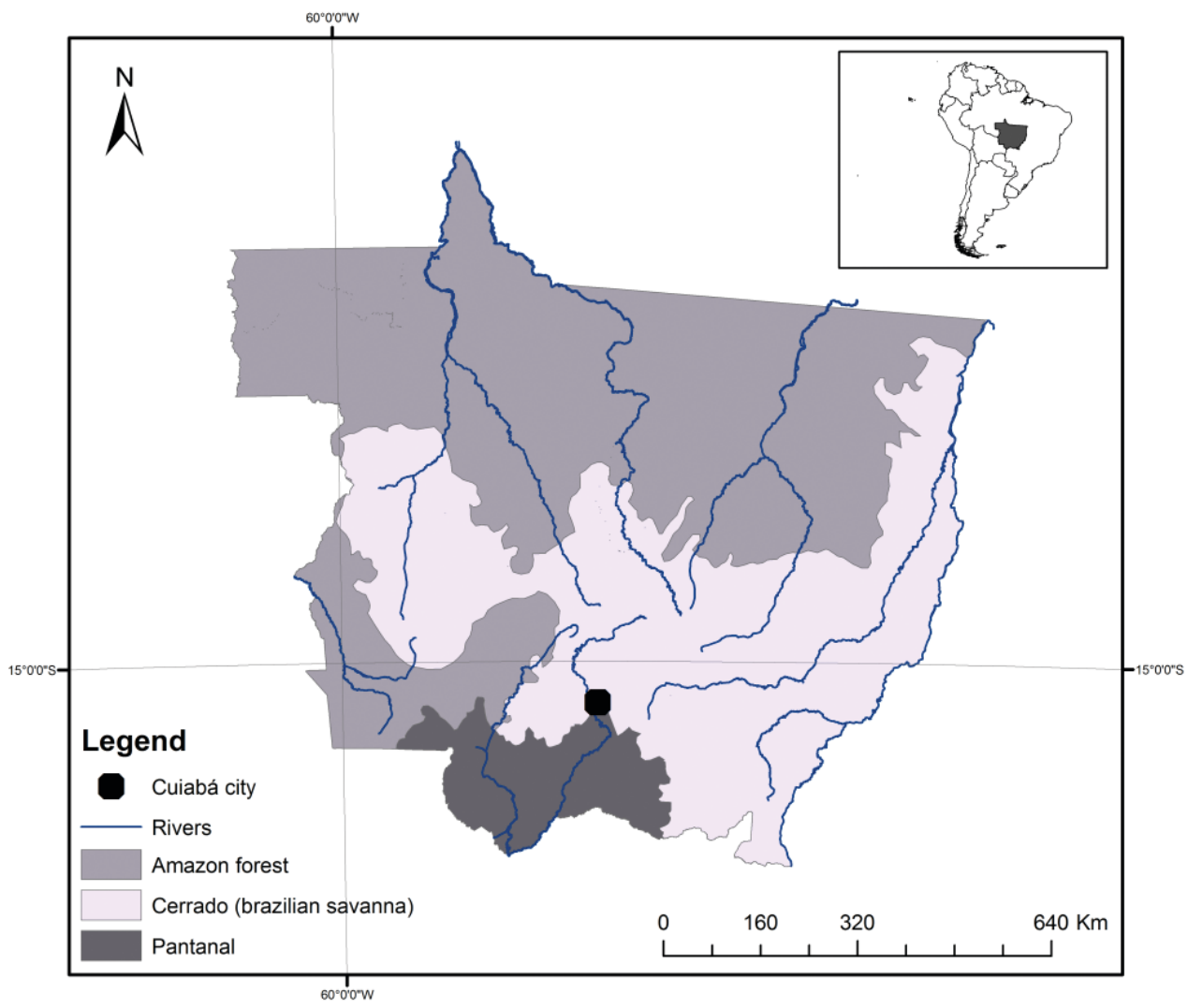

Figure 1 - Location of Cuiabá, Mato Grosso, Brazil. 
Table 1 - Solar radiation (Rg), precipitation (Ppt), maximum air temperature (Tmax), average air temperature $(\mathrm{T})$, minimum air temperature $(\mathrm{Tmin})$, relative air humidity $(\mathrm{RH})$, wind speed (Wspeed) and direction (Wdirection) used to characterize climate in Cuiabá.

\begin{tabular}{|c|c|c|c|c|c|c|c|c|}
\hline Year & Rg & Ppt & Tmax & T & Tmin & RH & Wspeed & Wdirection \\
\hline 1961 & $X$ & & $X$ & & & $X$ & $X$ & $X$ \\
1962 & $X$ & $X$ & $X$ & $X$ & $X$ & $X$ & $X$ & $X$ \\
1963 & $X$ & $X$ & $X$ & $X$ & $X$ & $X$ & $X$ & $X$ \\
1964 & $X$ & $X$ & $X$ & $X$ & $X$ & $X$ & $X$ & $X$ \\
1965 & $X$ & $X$ & $X$ & $X$ & $X$ & $X$ & $X$ & $X$ \\
1966 & $X$ & $X$ & $X$ & $X$ & $X$ & $X$ & $X$ & $X$ \\
1968 & $X$ & $X$ & $X$ & $X$ & $X$ & $X$ & $X$ & $X$ \\
1969 & $X$ & $X$ & $X$ & $X$ & $X$ & $X$ & $X$ & $X$ \\
1970 & $X$ & $X$ & $X$ & $X$ & $X$ & $X$ & $X$ & $X$ \\
1971 & $X$ & $X$ & $X$ & & & $X$ & $X$ & $X$ \\
1972 & $X$ & $X$ & $X$ & $X$ & $X$ & $X$ & $X$ & $X$ \\
1973 & $X$ & $X$ & $X$ & $X$ & $X$ & $X$ & $X$ & $X$ \\
1974 & $X$ & $X$ & $X$ & & & $X$ & $X$ & $X$ \\
1975 & $X$ & & $X$ & $X$ & $X$ & $X$ & $X$ & $X$ \\
1976 & $X$ & $X$ & $X$ & $X$ & $X$ & $X$ & $X$ & $X$ \\
1977 & $X$ & $X$ & $X$ & $X$ & $X$ & $X$ & $X$ & $X$ \\
1979 & $X$ & $X$ & $X$ & $X$ & $X$ & & $X$ & \\
1980 & $X$ & $X$ & $X$ & $X$ & $X$ & & $X$ & \\
1981 & $X$ & $X$ & $X$ & $X$ & $X$ & & $X$ & \\
1982 & $X$ & $X$ & $X$ & $X$ & $X$ & & $X$ & \\
1983 & $X$ & $X$ & $X$ & $X$ & $X$ & $X$ & $X$ & $X$ \\
1984 & $X$ & $X$ & $X$ & $X$ & $X$ & $X$ & $X$ & $X$ \\
1985 & $X$ & $X$ & $X$ & $X$ & $X$ & $X$ & $X$ & $X$ \\
1986 & $X$ & $X$ & $X$ & $X$ & $X$ & $X$ & $X$ & \\
1987 & & $X$ & $X$ & $X$ & $X$ & & $X$ & \\
1988 & & $X$ & $X$ & $X$ & $X$ & & $X$ & \\
1989 & & $X$ & & & $X$ & & $X$ & \\
1998 & & & $X$ & $X$ & $X$ & & $X$ & $X$ \\
1999 & & & $X$ & & & $X$ & $X$ & $X$ \\
2000 & & & $X$ & $X$ & $X$ & $X$ & $X$ & $X$ \\
2001 & & & & & $X$ & $X$ & $X$ & $X$ \\
2003 & $X$ & & & & & $X$ & $X$ & $X$ \\
2004 & & $X$ & & & & $X$ & $X$ & $X$ \\
2007 & & $X$ & & & & $X$ & $X$ & $X$ \\
2010 & & & $X$ & $X$ & $X$ & $X$ & & \\
2011 & & $X$ & $X$ & $X$ & $X$ & $X$ & & \\
\hline & & & & & & & & \\
\hline
\end{tabular}

seasons (the rainy season from October to April, and dry season from May to September) caused significant variations ( $p$-value $<0.05)$ in meteorological variables.

\section{RESULTS AND DISCUSSION}

The interannual variability of the precipitation corresponded to a maximum value of $1829.6 \mathrm{~mm} \mathrm{y}^{-1}$ in 1983 , a minimum of
$999.2 \mathrm{~mm} \mathrm{y}^{-1}$ in 1969, and a mean value of $1372.2 \mathrm{~mm} \mathrm{y}^{-1}$ (Fig. 2a). There were 17 years that the precipitation was lower and 11 years higher than the average precipitation of the study period, which corresponded to 68 and $32 \%$ of years, respectively.

The annual precipitation accumulated in this study was similar to the values of $1347.8 \mathrm{~mm}$ found in Santo Antônio do Leverger (Diniz et al., 2008), 1578.9 mm in Barra do Garças (Alves 
Table 2 - Wind directions, symbology and direction in degrees.

\begin{tabular}{|c|c|c|}
\hline $\begin{array}{c}\text { Wind } \\
\text { directions }\end{array}$ & Symbology & Degrees \\
\hline North & N & 0 to $23^{\circ}$ and 337 to $360^{\circ}$ \\
Northeast & NE & 24 to $68^{\circ}$ \\
East & E & 69 to $113^{\circ}$ \\
Southeast & SE & 114 to $158^{\circ}$ \\
South & S & 159 to $203^{\circ}$ \\
Southwest & SW & 204 to $248^{\circ}$ \\
West & W & 249 to $293^{\circ}$ \\
Northwest & NW & 294 to $336^{\circ}$ \\
\hline
\end{tabular}
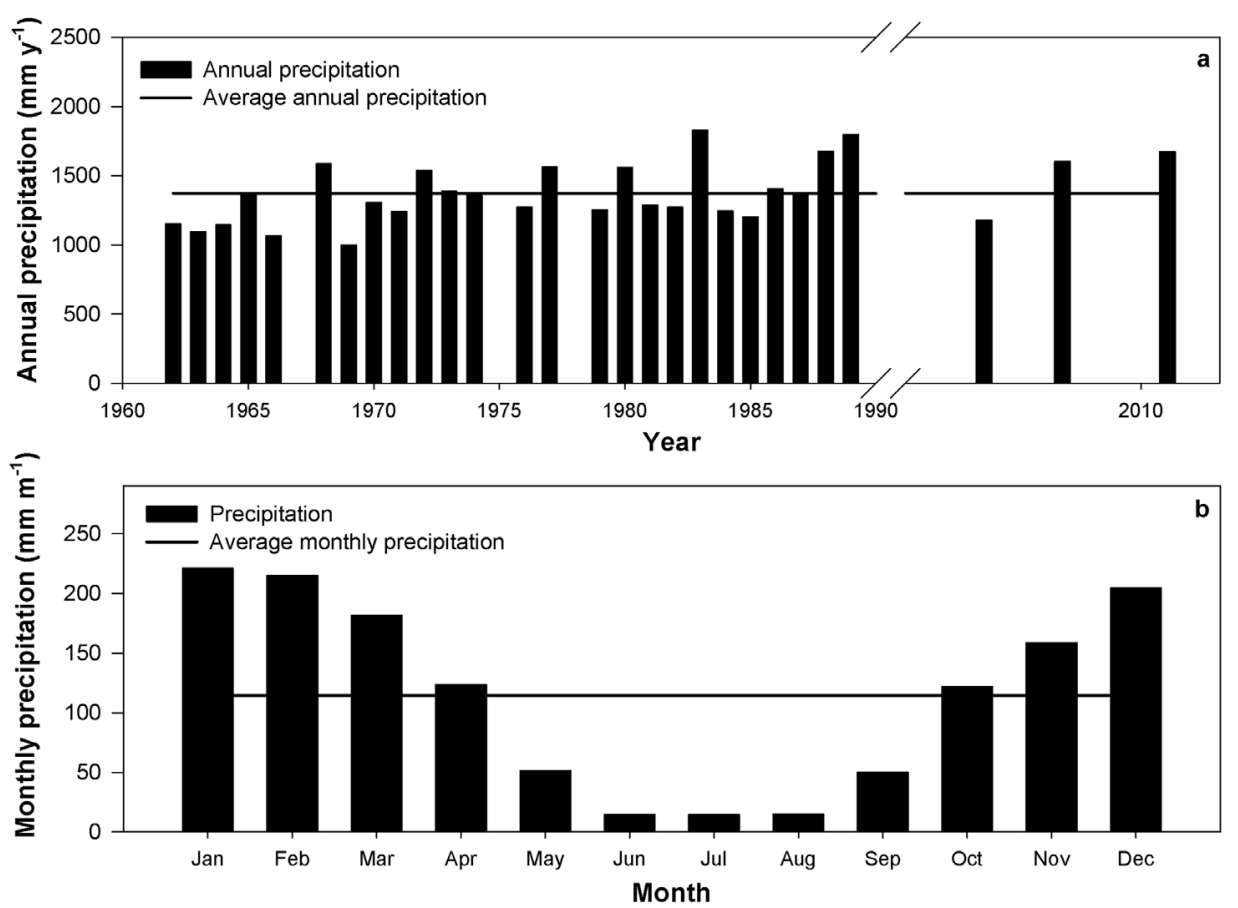

Figure 2 - Interannual (a) and monthly (b) variability of accumulated precipitation in Cuiabá.

et al., 2011) and approximately $1300 \mathrm{~mm}$ in Cáceres (Silva Neves et al., 2011; Pizzato et al., 2012). However, the average of precipitation was lower than values of $1830 \mathrm{~mm}$ found in Tangará da Serra (Dallacort et al., 2011) and of $2750 \mathrm{~mm}$ in municipalities further North of Mato Grosso (Sousa et al., 2006). Other studies also suggest that there is interannual variability of precipitation in several places in Mato Grosso (Rosa et al., 2007; Diniz et al., 2008; Alves et al., 2011; Dallacort et al., 2011; Silva Neves et al., 2011; Marcuzzo et al., 2012; Pizzato et al., 2012), which should be related with the altitude and vegetation aspect of each place Apparently, the interannual precipitation had a random variation a long of the study period. Probably the interannual variability is related with large scale climatological phenomenon, such as El Niño South Oscillation (ENSO), which is an oscillation coupling ocean-atmosphere interaction. The alteration on the Sea Surface Temperature (SST) modify the air pressure and wind and tropical convection is noticed which interferes in the whole atmospheric pattern circulation and switch the precipitation regime in many places around the word, including Brazil (Grimm, 2009).

During the study period, the mean annual occurrence of rainy days was 123 days and 242 dry days (Fig. 3a). The year 2004 had the longer of dry days with 265 days and the year 1977 had the longer rainy days with 213 days. The mean monthly occurrence of rainy days was 15 days in the rainy season while the 

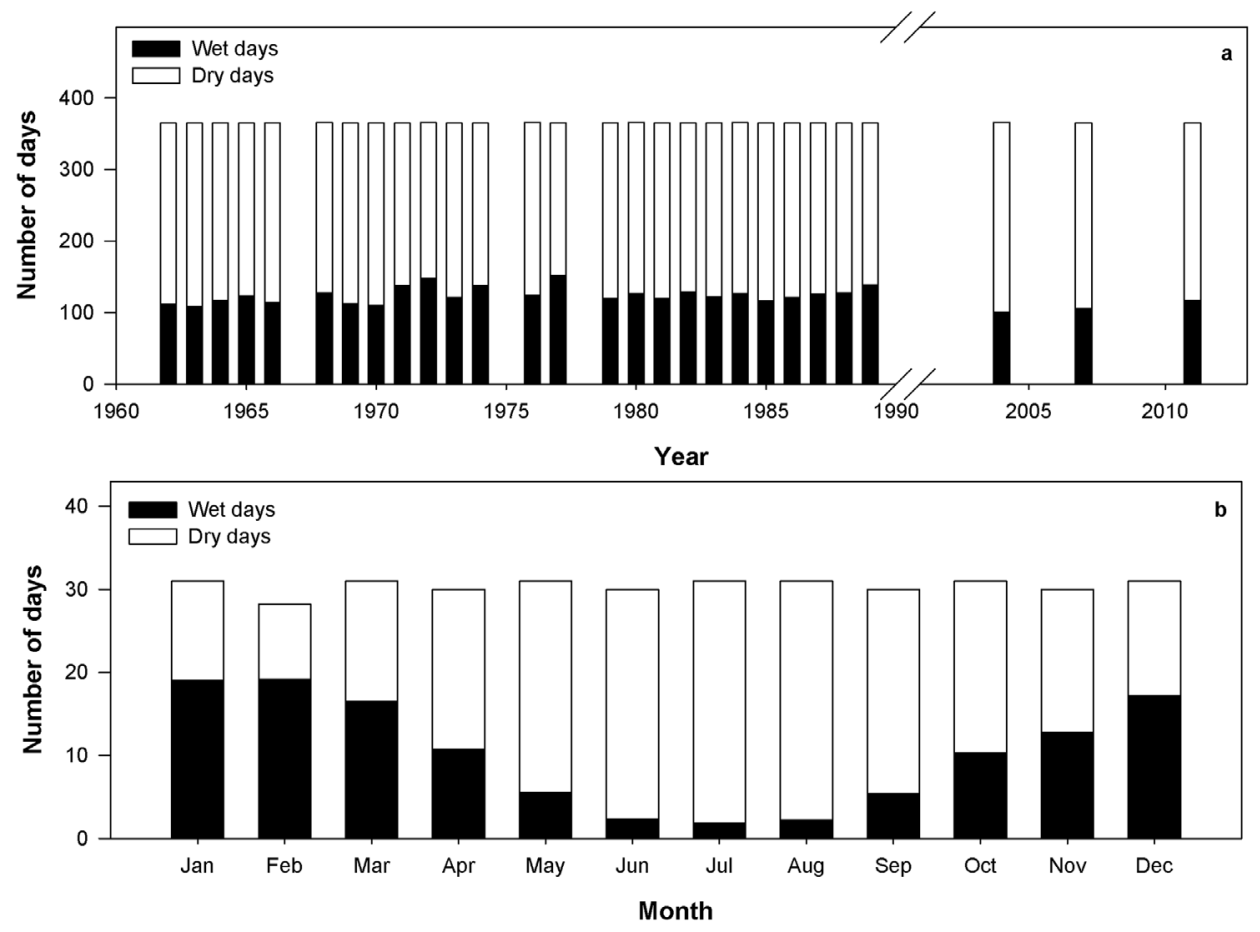

Figure 3 - Interannual (a) and monthly (b) variability of dry and wet days in Cuiabá

occurrence of dry days was 27 days in the dry season (Fig. 3b). February had the longer period of rainy days with 19 days and July had the longer period of dry days with 29 days.

Table 3 - Mann-Whitney Test for seasonal effect (dry and wet season) in precipitation (ppt), solar radiation (gr), maximum temperature (Tmax), average temperature $(\mathrm{T})$, minimum temperature (Tmin), relative humidity (RU), and wind speed (Wspeed).

\begin{tabular}{|c|c|c|c|}
\hline Variables & Treatment & W & $p$-value \\
\hline Ppt & season & 35 & 0.002 \\
Gr & season & 33 & 0.010 \\
Tmax & season & 22 & 0.530 \\
T & season & 34 & 0.005 \\
Tmin & season & 35 & 0.002 \\
RU & season & 32 & 0.017 \\
Wspeed & season & 26 & 0.202 \\
\hline
\end{tabular}

There was a significant seasonal variation in the precipitation (Table 3). The rainy season from October to April corresponded to $89 \%$ of precipitation while dry season from May to September corresponded to $11 \%$. The monthly variability of precipitation reaches to a maximum value of $220.9 \mathrm{~mm} \mathrm{~m}^{-1}$ in January and a minimum of $14.6 \mathrm{~mm} \mathrm{~m}^{-1}$ in July, whereas the mean value is $114.4 \mathrm{~mm} \mathrm{y}^{-1}$ (Fig. 2a). Studies also indicate that there is monthly variability of precipitation in several places in Mato Grosso with drought period from June to August (Sousa et al., 2006; Diniz et al., 2008; Dallacort et al., 2011; Silva Neves et al., 2011; Biudes et al., 2012). The Continental Equatorial Mass act in Cuiabá during the summer, which is characterized by strong air convection and the consequent formation of clouds with great vertical development. It is formed in low-pressure areas in the Amazon region due to large availability of heat, humidity and especially by the convergence of the winds from the SE Atlantic. In addition, the Continental Tropical Mass act during this period. Its origin associated with the thermal depression of the Chaco, where is a low-pressure region that attract the humidity from the Amazon and increase the amount of precipitable water (Nimer, 1989).

The annual variability of solar radiation corresponded to a maximum value of $17.5 \mathrm{MJ} \mathrm{m}^{-2} \mathrm{~d}^{-1}$ in November, a minimum of $13.5 \mathrm{MJ} \mathrm{m}^{-2} \mathrm{~d}^{-1}$ in June, and an average value of $15.6 \mathrm{MJ} \mathrm{m}^{-2}$ $\mathrm{d}^{-1}$ (Fig. 4a). There was a significant seasonal variation in solar radiation (Table 3), with the highest values registered during the rainy season (16.3 $\left.\mathrm{MJ} \mathrm{m}^{-2} \mathrm{~d}^{-1}\right)$ and the lowest values during dry season (14.6 MJ m${ }^{-2} \mathrm{~d}^{-1}$ ). The difference on the amount of solar radiation between both seasons here discussed agreed with austral period. In November, for example, is right before the official summer on the south hemisphere, besides that this month 
the sun cross exactly the latitude of Cuiabá. It implies that the sun rays will reach the surface perpendicularly, and consequently less radiation tends to be attenuated due to the smallest Zenith Angle and the smallest atmospheric optical way (Iqbal, 1983; Querino et al., 2006, 2011). On the other hand, the lowest values in June coincides with beginning of the winter period on the south hemisphere, as a result less radiation on the top of the atmosphere.

Others factors that determine the variation of solar radiation in the Amazon forest region are seasonal changes in cloud cover and vegetation burn (da Rocha et al., 2004). A recent study in Cuiabá had detected a large number of burning and hot spots during the dry season due to the low precipitation and relative humidity (Machado et al., 2014). Querino et al. (2006) have noticed smaller values of incoming solar radiation over pasture areas than over natural forest in Amazônia due to the fire during the amazon dry season. Artaxo et al. (2006) observed an increment on the aerosols concentration in the atmosphere because of burning, which increases the solar radiation attenuation (almost $70 \%$ of the photosynthetically active radiation is absorbed), and modifies the radioactive balance.

The mean annual temperature was $26.9^{\circ} \mathrm{C}$, the average maximum and minimum annual temperature $32.8^{\circ} \mathrm{C}$ and $21.2^{\circ} \mathrm{C}$, respectively (Fig. 4b). The average mean and minimum temperature were significantly higher during the rainy season (27.9 and $23.0^{\circ} \mathrm{C}$ ) and lower during the dry season $\left(25.5\right.$ and $\left.18.7^{\circ} \mathrm{C}\right)$, but the seasonal average maximum temperature $\left(30.0^{\circ} \mathrm{C}\right)$ had no significant difference (Table 3). The temperature gradient was greater in the dry season than in the wet season. The temperature followed seasonal pattern of the region (Biudes et al., 2012; 2014a). The highest values of temperature in the rainy season are related to higher availability of solar radiation (Biudes et al., 2012), which corroborates with the solar radiation results here presented. Besides the lowest values and the highest amplitude of the temperature observed during the dry season could be in response to the periodic appearances of cold fronts locally called "friagem" (Marengo \& Nobre, 2009; Biudes et al., 2012).

According to Seluchi (2009), friagem normally happen because of a well-defined synoptic pattern. The main characteristics of this system are a low precision over the South Atlantic Ocean and a high pressure on the medium and up level of the atmosphere over the Pacific Ocean. The combination of both systems determine the presence of a cold migratory anticyclone on the low level of the atmosphere and the contact between two different air masses (cold from the polar mass and warm from the continent) with distinct thermodynamic characteristic originate the cold fronts (Silva et al., 2014). Satyamurty \& Mattos (1989) have identified on the center-south of the South America that this region is located between two subtropical anticyclones and affirm that the cold front is associated to the baroclinic perturbation originally from the Pacific, that usually cross the Andes in medium latitude. The polar air commonly changes the atmospheric pressure and wind fields decreasing the temperature of the air when it is advancing through the continent (Rodrigues et al., 2004; Seluchi, 2009).

The mean annual relative humidity was $71.6 \%$ with maximum value in February (80\%) and minimum in August (56.7\%) (Fig. 4c), which implies higher relative humidity average during the rainy season (75.9\%) than dry season (65.5\%) (Table 3). The increase in relative humidity during therainy season is associated to the cold fronts systems that use to be stationary on the South Atlantic Ocean for 3 or more days. Such condition, organizes a moisture canal, which extends from south of Amazônia until the southeast of Brazil, increasing the presence of water vapor in the air, associated with large amount precipitation, named South Atlantic Convergence Zone (SACZ) (Kousky, 1988; Kodama, 1992, Quadro, 1994; Alves et al., 1999; Carvalho et al., 2004; Escobar, 2014).

Besides the SACZ the Intertropical Convergence Zone (ITCZ) is also placed more to the south in the rainy season. It helps the transport of the moisture from the ocean to the countryside. According to Melo et al. (2009) ITCZ is formed by the confluence of the trade winds, is characterized by a convective cloud band and is considered one of the most important precipitation maker on equatorial regions. The authors affirmed also that the association with others system such SACZ is extremely important to define the quality of the rainy period on north region of Brazil, and consequently corroborating to the elevation or reduction of relative humidity.

The lowest values of relative humidity in the dry season are associated to lowest availability of soil water, which causes a decrease in evapotranspiration and consequent increase in sensible heat flux (Wright et al., 1996; Biudes et al., 2009). During the dry season, the Continental Tropical Mass has no significant activity and the influence of Continental Equatorial Mass about Cuiabá is reduced, and the Atlantic Tropical Mass and the Atlantic Polar Mass activity increase. These masses are anticyclone systems that cause atmospheric stability and prevent the formation of convective cloud because tends to bring the dry air from up atmosphere to the surface and as consequence, precipitation is suppressed and relative humidity decrease (Nimer, 1989).

According to Marengo \& Nobre (2009), during the winter the circulation on high level of the atmosphere is characterized by 

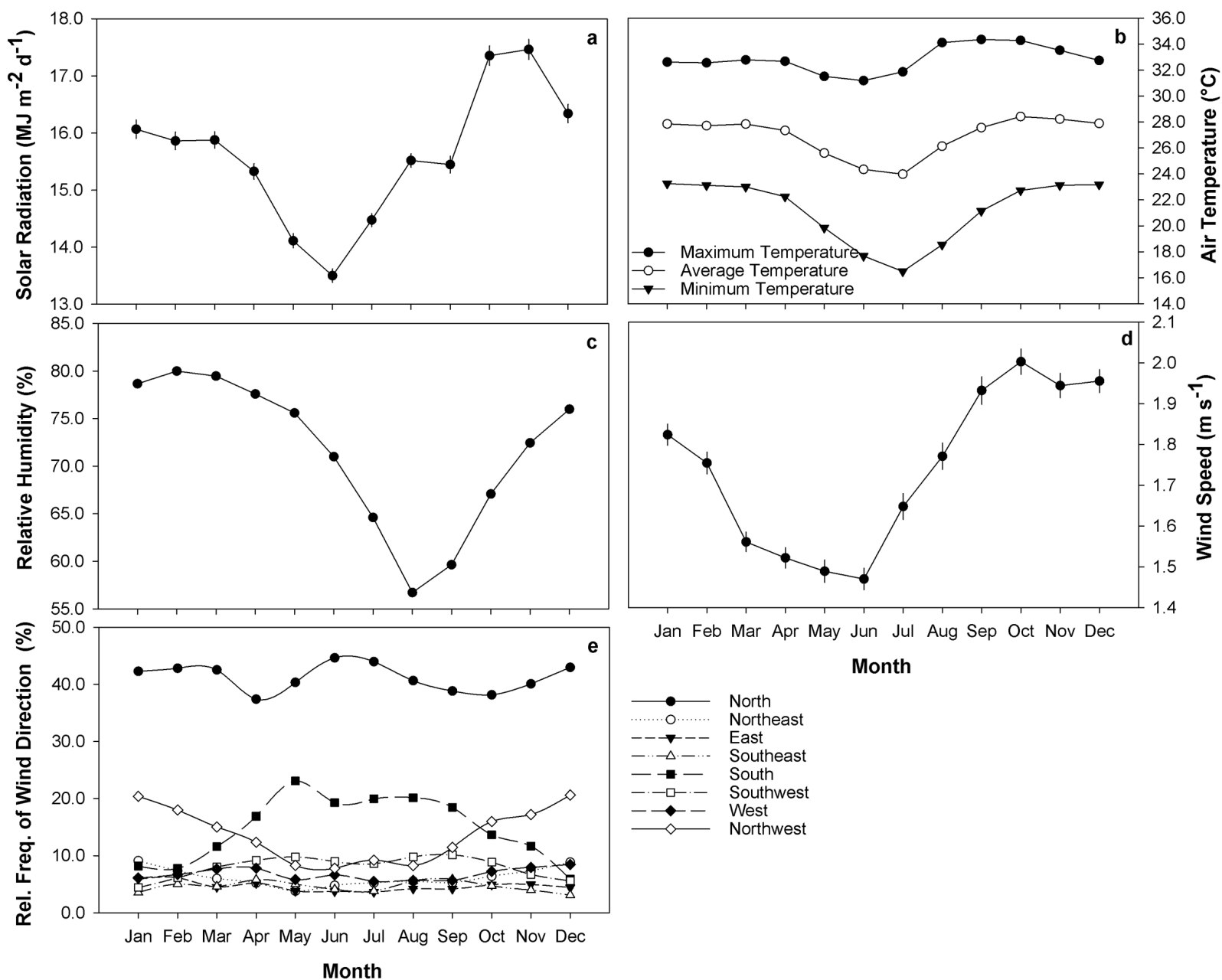

Jan Feb Mar Apr May Jun Jul Aug Sep Oct Nov Dec

Month

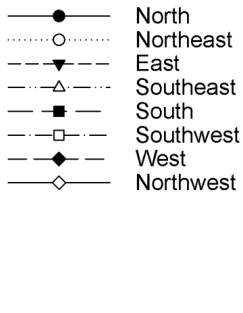

Figure 4 - Monthly average and standard error of solar radiation (a), maximum, average and minimum air temperature (b), relative humidity (c), wind speed (d), and wind direction (e) in Cuiabá, Mato Grosso, Brazil.

the weakening of the air fluxes over the tropic region. It means that the subtropical wind jet on high level becomes stronger and positioned close to the equator than in the summer season, in agreement with the downdraft of the Hadley's Circulation. The authors also observed that in low level of the atmosphere ITCZ is positioned on the north hemisphere reducing the moisture transport into the continent. Those combinations of factors result in relative humidity decline.

The annual mean of wind speed was $1.7 \mathrm{~m} \mathrm{~s}^{-1}$, the maximum value occurs in October $\left(2.0 \mathrm{~m} \mathrm{~s}^{-1}\right)$ and the minimum in June $\left(1.5 \mathrm{~m} \mathrm{~s}^{-1}\right)$ (Fig. 4d). There was no significant seasonal difference between the rainy $\left(1.8 \mathrm{~m} \mathrm{~s}^{-1}\right)$ and dry $\left(1.7 \mathrm{~m} \mathrm{~s}^{-1}\right)$ seasons. The wind occurs due to the gradient pressure between two points (Pereira et al., 2002), but it's also influenced by the Earth rotation, centrifugal force to its movement, as well as the topography
(Tubelis \& Nascimento, 1984). Cuiabá is located in a depression surrounded by Plateaus, which causes low frequency and average wind speed, minimizing heat exchange by convection (Vilanova \& Maitelli, 2009). The wind speed is higher in near towns localized in higher altitudes than Cuiabá and the maximum and minimum wind speed occurs in different period, as the example of Tangará da Serra, which has higher values in August $\left(3.5 \mathrm{~m} \mathrm{~s}^{-1}\right)$ and minimum in March (2.5 $\mathrm{m} \mathrm{s}^{-1}$ ) (Dallacort et al., 2010).

There was a predominance of wind from the North $(\mathrm{N})$ in Cuiabá (Fig. 4e). In the dry season, there was a decreasing in the frequency of wind direction from Northwest (NW) and a increasing of the occurrence of wind from the South (S). This wind pattern characterizes a typical monsoon regime (Santanna et al., 2008), which causes rainy summers and dry winters due to seasonal reversal of wind direction (Gan et al., 2009). This study area 
is located under the influence of the Atlantic Tropical Mass and the Atlantic Polar Mass to beyond the Chaco and Amazon depressions during the winter (Keller-Filho et al., 2005).

It is noteworthy that, the seasonal pattern of meteorological variables are mainly controlled by large and mesoscale systems in the Central-West Region of Brazil where the study area is located. The Central-West Region of Brazil is under climatic influence of tropical and subtropical atmosphere systems (Alves, 2009). During wet season, South Atlantic Convergence Zone (SACZ) is associated to a humidity convergent outflow from Amazônia to Brazilian Southeast passing through Central-West Region, which is responsible by rain extreme events. On the other hand, SACZ absence can cause rain suppression and long periods of drought (Carvalho \& Jones, 2009). There are still cold surges, or friagem, caused by outbreaks of polar air during wintertime (May-August), with low temperatures in midlatitudes, which affect southern Brazil with considerable cooling in central and northern Amazônia (Parmenter, 1976; Marengo et al., 1997).

\section{CONCLUSIONS}

The climate of Cuiabá is characterized by two distinct seasons, a dry (May to September) and a wet (October to April) and it is mainly driven by large scale climatological phenomenon. The rainiest month is January in while the driest is July. Cuiabá has drier days than rainier days during the year. The interannual variability of precipitation is driven by meso-large scale atmospheric system, such as cold fronts, SACZ, ITCZ. The peak of solar radiation is reached on the beginning of summer season and it is basically due to astronomical factors. Maximum and minimum average temperatures present the same standard of solar radiation reaching its values in November and July, respectively. Other important factor was the predominance of friagem during the winter (dry season) that decreases the average temperature. The highest values of relative humidity occur during the rainy season, mainly due to the SACZ and the Continental Tropical Mass. On the other hand, the lowest values of relative humidity occur during the dry season due to the displacement of atmospheric systems, as well as the total inhibition of others, such Bolívia High Pressure. The wind speed is low in Cuiabá and had no seasonal variation due to the topography. The wind direction is predominantly from $\mathrm{N}$ during whole year. Although, South direction frequency is commonly observed during the winter season due to the advance of polar mass through the continent.

\section{ACKNOWLEDGEMENTS}

This work was supported in part by the Universidade Federal de Mato Grosso (UFMT), Instituto Federal de Mato Grosso (IFMT),
Programa de Pós-Graduação em Física Ambiental (PPGFA) IF/UFMT, Centro Gestor e Operacional do Sistema de Proteção da Amazônia (CENSIPAM), Instituto Nacional de Meteorologia (INMET), Coordenação de Aperfeiçoamento de Pessoal do Ensino Superior under Grant [number 9750/13-4 and 9768/13-0], Fundação de Amparo à Pesquisa do Estado de Mato Grosso under Grant [FAPEMAT - PRONEM 2014 - Code: 561397/2014].

\section{REFERENCES}

ALVES LM. 2009. Clima da Região Centro-0este do Brasil. In: CAVALCANTI IFA, FERREIRA NJ, SILVA MGAJ \& DIAS MAFS (Eds.). Tempo e Clima no Brasil. São Paulo: Oficina de Textos, 235-241.

ALVES FSM, FISCH G \& VENDRAME IF. 1999. Modificações do microclima e regime hidrológico devido ao desmatamento na Amazônia: um estudo de caso em Rondônia (R0), Brasil. Acta Amazônica, 29(3): 395-409.

ALVES EDL, PRADO MF \& SPECIAN V. 2011. Análise da Variabilidade Climática da Precipitação pluvial em Barra do Garças, Mato Grosso. Brazilian Geographical Journal: Geosciences and Humanities Research, 2(2): 512-523.

ARTAXO P, OLIVEIRA PH, LARA LL, PAULIQUEVIS TM, RIZZO LV, PIRES JUNIOR C, PAIXÃO MA, LONGO KM, DE FREITAS S \& CORREIA AL. 2006. Efeitos climáticos de partículas de aerossóis biogênicos emitidos em queimadas na Amazônia. Revista Brasileira de Meteorologia (RBMET), 21(3a): 168-189.

BASTOS TX, GOMES MRA \& CORRÊA M. 1997. Padrão climático e variabilidade das chuvas em Tomé-Açu e sua implicação para as culturas da pimenta-do-reino e cupuaçu. Anais de Embrapa Amazônia Oriental: JICA, EMBRAPA.

BIUDES MS, CAMPELO JÚNIOR JH, NOGUEIRA JS \& SANCHES L. 2009. Estimativa do balanço de energia em cambarazal e pastagem no norte do Pantanal pelo método da razão de Bowen. Revista Brasileira de Meteorologia, 24(2): 135-143.

BIUDES MS, NOGUEIRA JS, DALMAGRO HJ, MACHADO NG, DANELICHEN VHM \& SOUZA MC. 2012. Mudança no microclima provocada pela conversão de uma floresta de cambará em pastagem no norte do Pantanal. Revista de Ciências Agro-Ambientais, 10(1): 61-68.

BIUDES MS, MACHADO NG, DANELICHEN VHM, SOUZA MC, VOURLITIS GL \& NOGUEIRA JS. 2014a. Ground and Remote Sensing-Based Measurements of Leaf Area Index in a Transitional Forest and Seasonal Flooded Forest in Brazil. International Journal of Biometeorology, 58(6): 1181-1193.

BIUDES MS, SOUZA MC, MACHADO NG, DANELICHEN VHM, VOURLITIS GL \& NOGUEIRA JS. 2014b. Modelling gross primary production of a tropical semi-deciduous forest in the southern Amazon Basin. International Journal of Remote Sensing, 35(4): 1540-1562. 
BIUDES MS, VOURLITIS GL, MACHADO NG, ARRUDA PHZ, NEVES GAR, LOBO FA, NEALE CMU \& NOGUEIRA JS. 2015. Patterns of energy Exchangefor tropical ecosystems across a climate gradiente in Mato Grosso, Brazil. Agricultural and Forest Meteorology, 202: 112-124.

BONAN GB. 2008. Forests and Climate Change: Forcings, Feedbacks, and the Climate Benefits of Forests. Science, 320: 1444-1449.

BRASIL. Ministério das Minas e Energia, Departamento Nacional da Produção Mineral. Projeto RADAMBRASIL. 1982. Folha SD 21 - Cuiabá, Levantamento dos recursos naturais. Rio de Janeiro: Ministério das Minas e Energia/Departamento da Produção Mineral, 26: 526 pp.

BRASIL. Ministério do Meio Ambiente, dos Recursos Hídricos e da Amazônia Legal. 1997. Plano de conservação da Bacia do Alto Paraguai: diagnóstico dos meios físicos e biótico. Meio físico. Brasília, Ministério do Meio Ambiente, dos Recursos Hídricos e da Amazônia Legal, Programa Nacional do Meio Ambiente, 2, $334 \mathrm{pp}$.

CALLEJASIJA, OLIVEIRA AS, SANTOS FMM, DURANTE LC, NOGUEIRA MCJA \& ZEILHOFER P. 2011. Relationship between land use/cover and surface temperature in the urban agglomeration of Cuiabá-Várzea Grande, Central Brazil. Journal of Applied Remote Sensing, 5(1): 553569

CARVALHO V, JONES C \& LIEBMANN B. 2004. The South Atlantic Convergence Zone: Persistence, Form, Extreme Precipitation and Relationships with Intraseasonal Activity. Journal of Climate, 17(1): 88-108.

CARVALHO LMV \& JONES C. 2009. Zona de Convergência do Atlântico Sul. In: CAVALCANTIIFA, FERREIRA NJ, SILVA MGJ \& SILVA DIAS MAF (Org.). Tempo e Clima no Brasil. 1 ed., São Paulo: Oficina de Textos, $1,96-109$

CHIARANDA R, RIZZI NE, COLPINI C, SOARES TS \& VERSIDES SM. 2012. Análise da precipitação e da vazão da bacia do Rio Cuiabá. Revista Brasileira de Ciências Agrárias, 7(1): 117-122.

CHRISTENSEN JH, BOBERG F, CHRISTENSEN OB \& LUCAS-PICHER P. 2008. On the need for bias correction of regional climate change projections of temperature and precipitation. Geophysical Research Letters, 35(20): L20709-L20705.

DA ROCHA HR, GOULDEN ML, MILLER SD, MENTON MC, PINTO LDVO, FREITAS HC \& FIGUEIRA AMS. 2004. Seasonality of water and heat fluxes over a tropical forest in eastern Amazonia. Ecological Applications, 14(4): S22-S32.

DALLACORT R, MOREIRA PSP, INOUE MH, SILVA DJ, CARVALHO IF \& SANTOS C. 2010. Wind speed and direction characterization in Tangará da Serra, Mato Grosso State, Brazil. Revista Brasileira de Meteorologia, 25(3): 359-364.

DALLACORT R, MARTINS JA, INOUE MH, FREITAS PSL \& COLETTI AJ. 2011. Distribuição das chuvas no município de Tangará da Serra, médio norte do Estado de Mato Grosso, Brasil. Acta Scientiarum. Agronomy, 33(2): 193-200.

DELIRE C, FOLEY JA \& THOMPSON S. 2004. Long-Term Variability in a Coupled Atmosphere-Biosphere Model. American Meteorological Society, 17: 3947-3959.

DINIZ GL, FONSECA M \& CAMPELO JUNIOR JH. 2008. Análise harmônica do regime de precipitação em duas localidades da baixada cuiabana. Biomatemática, 18: 37-48.

ESCOBARCJE. 2014. Padrões de circulação em superfície e em 500 hPa na América do Sul e eventos de anomalias positivas de precipitação no estado de Minas Gerais durante o mês de dezembro de 2011. Revista Brasileira de Meteorologia, 29(1): 105-124

FIETZ CR, COMUNELLOE, CREMON C \& DALLACORT R. 2008. Estimativa da precipitação provável para o Estado de Mato Grosso. Dourados: Embrapa Agropecuária Oeste, 237 pp.

GAN M, RODRIGUES LR \& RAO VB. 2009. Monção na América do Sul. In: CAVALCANTI IFA, FERREIRA NJ, SILVA MGAJ \& DIAS MAFS (Eds.). Tempo e Clima no Brasil. São Paulo: Oficina de Textos, 297-316.

GASH JHC \& NOBRE CA. 1997. Climatic Effects of Amazonian Deforestation: Some Results from ABRACOS. Bulletin of the American Meteorological Society, 78: 823-830.

GOMES FJD, SANCHES L, ALVES MC, NOGUEIRA MCJA \& NOGUEIRA JS. 2012. The relationship between meteorological variables and clearness index for four urban/suburban areas of Brazilian Cities. Journal of Environmental Science and Engineering, B1: 890-900.

GRIM AM. 2009. Variabilidade Interanual do Clima do Brasil. In: CAVALCANTIIFA, FERREIRA NJ, SILVA MGAJ \& DIAS MAFS (Eds.). Tempo e Clima no Brasil. São Paulo: Oficina de Textos, 354-374.

GUARIM GN. 1991. Diagnóstico Florístico e Faunístico da cidade de Cuiabá. Relatório de Pesquisa, Convênio Universidade Federal de Mato Grosso/Prefeitura Municipal de Cuiabá. Brazil.

IQBAL M. 1983. An introduction to solar radiation. New York: Academic Press. 212 pp.

KALNAYE \& CAI M. 2003. Impact of Urbanization and Land-Use Change on Climate. Nature, 423: 528-531.

KELLER-FILHOT, ASSAD ED \& LIMA PRSR. 2005. Regiões pluviometricamente homogêneas no Brasil. Pesquisa Agropecuária Brasileira, 40(4): 311-322

KODAMA YM. 1992. Large-scale common features of subtropical precipitation zones (the Baiu frontal zone, the SPCZ, and the SACZ), Part I: Characteristics of subtropical zones. Journal of the Meteorological Society, 70: 813-835.

KOUSKY VE. 1988. Pentad outgoing longwave radiation climatology for the South American sector. Revista Brasileira de Meteorologia, 3: 217-231. 
LEUNG R, MEARNS LO, GIORGI F \& WILBY RL. 2003. Regional Climate Research: Needs and Opportunities. Bulletin of the American Meteorological Society, 84(1): 89-95.

MACHADO NG, da SILVA FCP \& BIUDES MS. 2014. Efeito das condições meteorológicas sobre o risco de incêndio e o número de queimadas urbanas e focos de calor em Cuiabá-MT, Brasil. Revista Ciência e Natura, 36(3): 459-469.

MARCUZZO FFN, OLIVEIRA NL, PINTO FILHO RF \& FARIA TG. 2012. Chuvas na região centro-oeste e no estado do Tocantins: análise histórica e tendência futura. Boletim de Geografia, 30(1): 19-30.

MARENGO JA \& NOBRE CA. 2009. Clima da Região Amazônica. In: CAVALCANTI IFA, FERREIRA NJ, SILVA MGAJ \& DIAS MAFS (Eds.). Tempo e Clima no Brasil. São Paulo: Oficina de Textos, 197-212.

MARENGO JA, CORNEJO A, SATYAMURTYP, NOBRE C \& SEA W. 1997. Cold Surges in Tropical and Extratropical South America: The Strong Event in June 1994. Monthly Weather Review, 125: 2759-2786.

MAURER EP, BREKKE L, PRUITT T \& DUFFY PB. 2007. Fine-resolution climate projections enhance regional climate change impact studies. Eos, Transactions American Geophysical Union, 88(47): 504.

MELO ABC, CAVALCANTI IF de A \& SOUZA PP. 2009. Zona de Convergência Intertropical do Atlântico. In: CAVALCANTI IFA, FERREIRANJ, SILVA MGAJ \& DIAS MAFS (Eds.). Tempo e Clima no Brasil. São Paulo: Oficina de Textos, 25-41.

NIMER E. 1989. Climatologia do Brasil. 2 ed., Rio de Janeiro, Brazil: Instituto Brasileiro de Geografia e Estatística, 421 pp.

PARMENTER FA. 1976. Southern Hemisphere cold front passage at the equator. Bulletin of the American Meteorological Society, 57: $1435-1440$.

PEEL MC, FINLAYSON BL \& McMAHON TA. 2007. Updated world map of the Köppen-Geiger climate classification. Hydrology and Earth System Sciences, 11(S1): 1633-1644.

PEREIRA AR, ANGELOCCI LR \& SENTELHAS PC. 2002. Agrometeorologia: fundamentos e aplicações práticas. Guaíba: Agropecuária, 478 pp.

PIZZATO JA, DALLACORT R, TIEPPO RC, MODOLO AJ, CREMON C \& MOREIRA PSP. 2012. Distribuição e probabilidade de ocorrência de precipitação em Cáceres (MT). Pesquisa Agropecuária Tropical, 42(2): 137-142.

QUADRO MFL. 1994. Estudo de Episódios de Zona de Convergência do Atlântico Sul (ZCAS) sobre a América do Sul. 1994. Master Dissertation in Meteorology, Instituto Nacional de Pesquisas Espaciais, São José dos Campos, Brazil. 123 pp.

QUERINO CAS, MOURA MAL, LYRA RFF \& MARIANO GL. 2006. Avaliação e comparação de radiação solar global e albedo com ângulo zênital na região Amazônica. Revista Brasileira de Meteorologia, 21(3a): 42-49.
QUERINO CAS, MOURA MAL, QUERINO JKAS, VON RADOW C \& MARQUES FILHO AO. 2011. Estudo da radiação solar global e do índice de transmissividade (Kt), externo e interno, em uma floresta de mangue em Alagoas - Brasil. Revista Brasileira de Meteorologia, 26(2): 204-294.

RAO VB, CAVALCANTI IFA \& HADA K. 1996. Annual variation of rainfall over Brazil and water vapor characteristics over South America. Journal of Geophysical Research: Atmospheres, 101(D21): 26536-26551.

RODRIGUES MLG, FRANCO D \& SUGAHARA S. 2004. Climatologia de Frentes Frias no Litoral de Santa Catarina. Brazilian Journal of Geophysics, 22(2): 135-151.

ROSA DB, SOUSA RR, NASCIMENTO LA, TOLEDO LG, TOPANOTTIDQ \& NASCIMENTO JAA. 2007. Distribuição espacial das chuvas na porção centro-oeste do Estado de Mato Grosso - Brasil. Revista Eletrônica da Associação dos Geógrafos Brasileiros, 1(5): 127-152.

SANTANNA FB, ARRUDA PHZ, FARIA JLB \& NOGUEIRA JS. 2008. EStudo preliminar da velocidade e direção dos ventos, em Cuiabá, MT, Brasil. Revista Brasileira de Agrometeorologia, 16(2): 175-180.

SANTOS FMM. 2013. Clima urbano de Cuiabá-MT-Brasil: ocupação do solo e suas influências. Revista Monografias Ambientais - REMOA, 12(12): 2749-2763

SATYAMURTY P \& MATTOS LF. 1989. Climatological lower tropospheric frontogenesis in the midlatitudes due to horizontal deformation and divergence. Monthly Weather Review, 117: 1355-1364.

SELUCHI ME. 2009. Geadas e Friagens. In: CAVALCANTI IFA, FERREIRA NJ, SILVA MGAJ \& DIAS MAFS (Eds.). Tempo e Clima no Brasil. São Paulo: Oficina de Textos, 150-167.

SILVA NEVES SMA, NUNES MCM \& NEVES RJ. 2011. Caracterização das condições climáticas de Cáceres/MT, Brasil, no período de 1971 a 2009: subsídio às atividades agropecuárias e turísticas municipais. Boletim Goiano de Geografia, 31(2): 55-68.

SILVA LJ, REBOITA MS \& ROCHA RP. 2014. Relação da passagem de frentes frias na região sul de Minas Gerais (RSMG) com a precipitação e eventos de rajada. Revista Brasileira de Climatologia, 14: 229-246.

SNYDER PK, DELIRE C \& FOLEY JA. 2004. Evaluating the influence of different vegetation biomes on the global climate. Climate Dynamics, 23: 279-302.

SOUSA RR, ROSA DB, NASCIMENTO LA \& LIMA PRM. 2006. Estudo da variabilidade pluviométrica no extremo norte do estado de Mato Grosso entre os anos de 1990 a 1996. Geoambiente, 7: 89-107.

SOUZA MC, BIUDES MS, DANELICHEN VHM, MACHADO NG, MUSIS CR, VOURLITIS GL \& NOGUEIRA JS. 2014. Estimation of gross primary production of the Amazon-Cerrado Transitional Forest by remote sensing techniques. Revista Brasileira de Meteorologia, 29(1): 1-12.

TUBELIS A \& NASCIMENTO FCL. 1984. Meteorologia descritiva: Fundamentos e aplicações brasileiras. São Paulo, Brazil: Nobel, 374 pp. 
VILANOVA SRF \& MAITELLI GT. 2009. A importância da conservação de áreas verdes remanescentes no Centro Político Administrativo de Cuiabá-MT. UNICiências, 13: 55-71.

WILKS DS. 2011. Statistical methods in the atmospheric sciences. Academic Press, $676 \mathrm{pp}$.

WRIGHT IR, NOBRE CA, TOMASELLAJ, DA ROCHA HR, ROBERTS JM, VERTAMATTI E, CULF AD, ALVALÁ RC, HODNETT MG \& UBARANA V. 1996. Towards a GCM surface parameterization for Amazonia. In: GASH JHC, NOBRE CA, ROBERTS JM \& VICTORIA RL (Eds.). Amazonian Deforestation and Climate. New York: John Wiley and Sons, 473-504.

XAVIER AL, NOGUEIRA MCJA, MAITELLI GT, OLIVEIRA AG, OLIVEIRA AS, SANTOS FMM \& NOGUEIRA JS. 2009. Variação da temperatura $e$ umidade entre áreas urbanas de Cuiabá. Engenharia Ambiental, 6(1): 82-93.

XIE S, XIE Q, WANG D \& LIU WT. 2003. Summer upwelling in the South China Sea and its role in regional climate variations. Journal of Geophysical Research, 108(C8): 3261.

ZAMPARONI CG. 2008. Riscos e desastres naturais em ambiente urbano: 0 exemplo de Cuiabá/MT. Revista Brasileira de Climatologia, 10: $7-20$.

ZEILHOFER P. 2001. Modelação de relevo e obtenção de parâmetros fisiográficos na Bacia do Rio Cuiabá. Revista Brasileira de Recursos Hídricos, 6(3): 95-109.

Recebido em 9 dezembro, 2014 / Aceito em 9 março, 2016

Received on December 9, 2014 / Accepted on March 9, 2016

\section{NOTES ABOUT THE AUTHORS}

Nadja Gomes Machado. Bachelor in Biology Science (2004), Master in Ecology and Conservation of Biodiversity (2004) and Doctor in Environment Physics (2013) by the Universidade Federal de Mato Grosso (UFMT) and Post-Doctorate in Environmental Sciences by the University of Utah. Currently is Professor at the Instituto Federal de Mato Grosso (IFMT) and Programa de Pós-Graduação em Física Ambiental of UFMT. Has experience in environment physics with spatial analysis, remote sensing and bioclimatology.

Marcelo Sacardi Biudes. Graduated in Licentiate Physics, Master in Environment Physics and Doctor in Tropical Agriculture at the Universidade Federal de Mato Grosso (UFMT). Detains Post-doctorate in Environmental Sciences by the University of Utah and California State University, San Marcos. Currently is Professor of UFMT at Physics Institute and in the Programa de Pós-Graduação em Física Ambiental of UFMT. Leader of the research group in Spatial Analysis Applied to Environmental Sciences, has experience in Environmental Sciences with emphasis on climatology, micrometeorology, remote sensing and spatial analysis.

Carlos Alexandre Santos Querino. Meteorologist at the Sistema de Proteção da Amazônia at regional center of Porto Velho - SIPAM - PVH. Bachelor and master in Meteorology by the Universidade Federal de Alagoas (2003) and (2006), respectively, and doctorate student at the Programa de Pós-Graduação em Física Ambiental of the Universidade Federal de Mato Grosso. Currently conducts research in the biosphere-atmosphere interaction in the Amazônia, relating solar radiation, radiative balance and energy with surface and satellite data. Has experience in Geosciences (Meteorology), with emphasis on solar radiation.

Victor Hugo de Morais Danelichen. Graduated in Licentiate Physics (2010), master and doctor in Environmental Physics (2012, 2015) at Universidade Federal de Mato Grosso. Has experience in Environmental Sciences with emphasis on Micrometeorology and use of orbital sensors in research involving energy balance. Also works with issues involving the integration of energy balance data and gross primary productivity with remote sensing data.

Maísa Caldas Souza Velasque. Graduated in Licentiate Physics (2010), master and doctor in Environmental Physics (2013, 2016) at Universidade Federal de Mato Grosso. Has experience in Physics, with emphasis on gross primary production and remote sensing. 